\title{
PROBLEM ZWIĄZANIA SĄDU POLUBOWNEGO PRZEPISAMI PRAWA MATERIALNEGO
}

Zagadnienie określone w tytule niniejszego artykułu od dłuższego czasu budzi spory w doktrynie procesu cywilnego i doktrynie prawa handlowego. Przyznać należy, że w judykaturze problem ten jest z kolei rozwiązywany w sposób jednolity, tj. na rzecz braku - co do zasady - formalnego i faktycznego związania sądów arbitrażowych normami prawa cywilnego i - szerzej całego prawa materialnego stanowiącego podstawę wyrokowania w postępowaniu arbitrażowym.

W sposób najbardziej rozbudowany pogląd o pełnym związaniu sądów polubownych przepisami prawa materialnego przedstawił $\mathrm{w}$ polskiej doktrynie P. Ballada w obszernej wypowiedzi na łamach „Ruchu Prawniczego, Ekonomicznego i Socjologicznego" ${ }^{1}$. W tamtym czasie obowiąywały jeszcze przepisy Kodeksu postępowania cywilnego o sądzie arbitrażowym w ich pierwotnym brzmieniu, tj. w brzmieniu sprzed nowelizacji z 2005 r. W obecnym brzmieniu przepisy arbitrażowe Kodeksu postępowania cywilnego tym bardziej jednak mogą być odczytywane w kierunku uznania, że prawo materialne (prawo właściwe dla danego stosunku - art. 1194 § 1) w pełnym zakresie wiąże sąd polubowny podczas wyrokowania. Przed rokiem 2005 omawiany tu problem uregulowany był w art. $712 \S 1$ pkt 4 k.p.c., zgodnie z którym strona mogła żądać uchylenia wyroku sądu polubownego, jeżeli „rozstrzygnięcie o żądaniach stron uchybiało praworządności lub zasadom współżycia społecznego Rzeczypospolitej Polskiej”. Obecnie problem ten został przeniesiony do art. $1206 \S 2$ pkt 2 , zgodnie z którym uchylenie wyroku sądu polubownego następuje także wtedy, gdy „wyrok sądu polubownego jest sprzeczny z podstawowymi zasadami porządku prawnego Rzeczypospolitej Polskiej (klauzula porządku publicznego)". Ponadto w 2005 r. pojawił się wspomniany wyżej art. $1194 \S 1$ nakazujący sądom polubownym rozstrzyganie sporu „według prawa właściwego dla danego stosunku, a gdy strony go do tego wyraźnie upoważniły - według ogólnych zasad prawa lub zasad słuszności”.

Stosowane przed 2005 r. pojęcie zasad współżycia społecznego budziło w praktyce liczne wątpliwości², a pojęcie praworządności wiązano często z poprzednim okresem ustrojowym, dlatego wprowadzono do k.p.c. stosowana

${ }^{1}$ P. Ballada, Zagadnienie obowiazku stosowania prawa materialnego $w$ postepowaniu przed sqdem polubownym, „Ruch Prawniczy, Ekonomiczny i Socjologiczny” 2002, z. 1, s. 87-103.

${ }^{2}$ T. Ereciński, w: Kodeks postępowania cywilnego. Komentarz. Część czwarta i piata, t. 5, Warszawa 2009, s. 729. 
wcześniej w prawie prywatnym międzynarodowym i międzynarodowym postępowaniu cywilnym przesłankę klauzuli porządku publicznego. Istota jednak problemu przestrzegania prawa materialnego przez sądy polubowne pozostała niezmieniona. Warto też zauważyć wypowiedziany w judykaturze pogląd, że „zasady praworządności w Rzeczpospolitej Polskiej to w istocie nic innego jak jeszcze jedno wyrażenie klauzuli porządku publicznego"3.

P. Ballada zatem twierdził, że sąd polubowny powinien „realizować swoje cele w oparciu o normy prawa materialnego" ". Jego zdaniem przyjęcie poglądu o braku związania sądu polubownego częścią przepisów prawa materialnego prowadziłoby do uznania obowiazującego prawa za prawo złe. Autor ten przyznał, że naruszenia prawa materialnego niosa ze sobą mniejszą lub większa szkodliwość, ,jednakże żadne względy celowościowe nie powinny przesądzać o akceptacji, a tym bardziej usankcjonowaniu owych naruszeń" ostrzega, że pogląd o braku związania sądu polubownego przepisami prawa materialnego doprowadzi do tego, że sąd polubowny będzie je dowolnie interpretował, nie zwracając uwagi na intencje ustawodawcy, i to bez żadnych negatywnych konsekwencji takiego działania. Według niego prawo w takim przypadku zostaje sprowadzone do roli narzędzia, które miałoby służyć do osiagania celów stawianych sobie przez sąd polubowny. Dalej wywodził on, że nie uzyska pozytywnej oceny to państwo, w którym organy powołane i zobowiazane do kontroli praworządności zamiast uchylać bezprawne decyzje wydane z naruszeniem prawa będą je sankcjonować. Taką postawę sądów państwowych, które nie uchylają wyroku sądu polubownego z powodu jego sprzeczności z prawem materialnym, określił on jako szczególnie niebezpieczna. P. Ballada wyraził wręcz ubolewanie, że „można nierzadko spotkać w doktrynie i orzecznictwie próby uzasadnienia poglądu o niezwiązaniu sądu polubownego przepisami prawa materialnego"6.

$\mathrm{Z}$ poglądem o istnieniu związania sądu polubownego przepisami prawa materialnego nie sposób się jednak zgodzić. Pogląd ten nie znajdował żadnego uzasadnienia ani w poprzednim okresie, tj. przed 2005 r., ani też nie znajduje obecnie, gdy do k.p.c. wprowadzono część piątą obejmującą wyłącznie sądownictwo arbitrażowe. Stanowisko krytyczne wobec omawianego poglądu należy podtrzymać nawet w sytuacji, w której nowy w k.p.c. art. $1194 \S 1$ stwierdza, jak już wspomniano, że sąd polubowny rozstrzyga spór według prawa właściwego dla danego stosunku. Przemawia za tym kilka ważkich argumentów.

Przede wszystkim Kodeks nie ustanawia wymogu przygotowania prawniczego dla arbitrów zasiadających w składach orzekających sądów polubownych. Wymagania ustawowe wobec nich są bardzo ogólne i dotyczą posiadania pełnej zdolności do czynności prawnych i niewykonywania funkcji sędziego państwowego (art. 1170 k.p.c.). Nie zmienia tego fakt, że strony moga jeśli zechca, wymagać od kandydata na arbitra spełnienia wymogu określonych kwalifikacji, w tym również prawniczych (por. art. $1173 \S 1$ oraz $1174 \S 2$ k.p.c.).

\footnotetext{
${ }^{3}$ Wyrok SA w Gdańsku z 14 lipca 1995 r., I ACr 424/95, OSA 1995, nr 9, poz. 62.

${ }^{4}$ P. Ballada, op. cit., s. 94.

${ }^{5}$ Ibidem, s. 100 i 101.

${ }^{6}$ Ibidem, s. 102 i 94.
} 
Jest oczywiste, że nie można oczekiwać od nieprawnika, że będzie wydawał orzeczenia w pełni zgodne z przepisami prawa materialnego. Gdyby ustawodawca chciał, by wyroki arbitrażowe wydawane były lege artis, wprowadziłby wymóg posiadania przez arbitrów kwalifikacji prawniczych, a przede wszystkim wykształcenia prawniczego. Nie można przecież od człowieka nieznającego prawa oczekiwać wydawania rozstrzygnięć w pełni zgodnych z prawem.

Zwolennicy poglądu, że sądy polubowne są związane prawem materialnym, powołują się na wspomniany art. $1194 \S 1$, ale zauważyć trzeba, że w istocie jest to klasyczny przykład legis imperfectae. Brak bowiem wśród przepisów o skardze o uchylenie wyroku sądu polubownego takiego postanowienia, że $\mathrm{w}$ razie sprzeczności wyroku sądu polubownego z prawem wyrok ten podlega uchyleniu. Istnieje jedynie przepis nakazujący sądowi państwowemu z urzędu uwzględnić sprzeczność wyroku arbitrażowego z podstawowymi zasadami porządku prawnego Rzeczypospolitej Polskiej (art. 1206 § 2 pkt 2 k.p.c.). Nie można zatem skutecznie zakwestionować błędów w zakresie stosowania prawa materialnego przez sądy polubowne, gdyż aktualnie obowiąujące środki zaskarżenia na to nie pozwalajac. Można jedynie przyjąć, że w razie uzgodnienia w zapisie, że strony powołują w danej sprawie sąd polubowny dwuinstancyjny, strona ma prawo podnieść zarzut naruszenia prawa materialnego w odwołaniu do sądu polubownego II instancji.

Prawo właściwe, o którym mowa w art. $1194 \S 1$ k.p.c., to prawo materialne wskazane jako właściwe przez strony ${ }^{7}$ lub prawo uznane za właściwe przez skład orzekajacy sądu polubownego ${ }^{8}$ na podstawie norm kolizyjnych.

Interesujace rozważania na temat problemu zgodności wyroków sądów polubownych z prawem materialnym przeprowadziła J. Pazdan, łączacc to z kwestią autonomii woli stron przy zawieraniu umów. Swoje poglądy przedstawiła ona w opracowaniu pod prowokacyjnym tytułem Czy można wyłaczyć umowe spod prawa $?^{9}$ Doszła do konkluzji, że strony stosunku zobowiąaniowego moga osiagnaćc skutek „zbliżony do wyłączenia umowy spod prawa, poddając spór sądowi polubownemu oraz upoważniając arbitrów do orzekania według zasad prawa lub zasad słuszności”10.

W świetle przepisów części piątej k.p.c. wyrok sądu polubownego pomimo niezgodności z prawem materialnym obroni się w ewentualnym postępowaniu przed sądem państwowym wszczętym skargą o uchylenie wyroku sądu polubownego, jeżeli tylko wyrok ten nie naruszy podstawowych zasad porzadku prawnego RP, tj. nie będzie sprzeczny z klauzula porządku publicznego. Podstawowe zasady porządku prawnego obejmuja zasady konstytucyjne i ustrojowe porządkujące cały system prawny w Polsce. Do zasad tych zaliczono m.in. zasadę pacta sunt servanda ${ }^{11}$, zasadę autonomii woli stron oraz równości

\footnotetext{
7 A. Kąkolecki, P. Nowaczyk, w: System prawa handlowego, red. S. Włodyka, t. 8: Arbitra $\dot{z}$ handlowy, red. A. Szumański, Warszawa 2010, s. 80.

${ }^{8}$ M. Sujkowska, Materialnoprawne podstawy rozstrzygnięcia sporu $w$ postępowaniu arbitrażowym, „Ius Novum” 2008, nr 4, s. 115-116.

9 J. Pazdan, Czy można wytaczyć umowę spod prawa?, „Państwo i Prawo” 2005, z. 10, s. 5-18.

${ }^{10}$ Ibidem, s. 18.

${ }^{11}$ Wyrok SN z 8 grudnia 2006 r., V CSK 321/06, Lex, nr 322023.
} 
podmiotów ${ }^{12}$, zasadę kompensacyjnego charakteru odpowiedzialności odszkodowawczej ${ }^{13}$, zasadę równego traktowania wierzycieli w postępowaniu układowym ${ }^{14}$. W tym ostatnim orzeczeniu SN uznał za naruszenie podstawowych zasad porządku prawnego w postępowaniu arbitrażowym sytuację, gdy sąd polubowny zasądził odszkodowanie niewynikające $\mathrm{z}$ istniejącego między stronami stosunku prawnego. Do podstawowych zasad porządku prawnego zalicza się również zasadę swobody umów ${ }^{15}$. Ogólnie zasady te bywały też określane jako fundamentalne normy systemu prawnego ${ }^{16}$.

Za podstawowe zasady porządku prawnego można też przyjąć wszystkie zasady przewidziane w rozdziale II Konstytucji RP objęte artykułami 30 do $86^{17}$. Zdaniem SA w Katowicach do zasad tych należy również zaliczyć naczelne zasady rządzące poszczególnymi dziedzinami prawa - cywilnego, rodzinnego, pracy, a także prawa procesowego ${ }^{18}$.

Niewatpliwie do podstawowych zasad porządku prawnego przynależy również wyrażona w art. 20 Konstytucji RP zasada swobody działalności gospodarczej.

Wskazać można liczne przykładowe sytuacje, w których wyrok sądu polubownego będzie ewidentnie sprzeczny z prawem materialnym (cywilnym), ale jednocześnie nie będzie on naruszał podstawowych zasad porządku prawnego ani nie będzie podlegał uchyleniu. Rozważmy zatem sytuację, w której wierzyciel wytacza powództwo o zasądzenie swojej wierzytelności, ale czyni to dwa dni po upływie terminu przedawnienia roszczenia. Jeżeli powództwo to będzie rozpoznawał sąd powszechny, to po podniesieniu przez pozwanego zarzutu przedawnienia sąd państwowy ma bezwzględny obowiązek wydać wyrok oddalający powództwo. Każdy inny wyrok byłby tu sprzeczny z prawem, w tym przypadku z art. $117 \S 2$ k.c., i podlegałby skutecznemu zaskarżeniu. Jeżeli jednak w tej sprawie strony dokonałyby zapisu na sąd polubowny, a sąd ten uwzględniłby powództwo, to wyrok ten nie naruszyłby podstawowych zasad porządku prawnego. Przedawnienie roszczenia było bowiem niewielkie, a sam ustawodawca aż do $1990 \mathrm{r}$. pozwalał sądom państwowym na nieuwzględnianie przedawnienia, jeżeli było ono nieznaczne. Wskazany tu wyrok sądu po-

${ }^{12}$ Postanowienie SN z 9 marca 2004 r., I CK 412/03, Lex, nr 183721.

${ }^{13}$ Wyrok SN z 11 czerwca 2008 r., V CSK 8/08, Lex, nr 400965.

${ }^{14}$ Wyrok SN z 11 czerwca 2008 r., V CSK 8/08, Lex, nr 400965.

${ }^{15}$ Wyrok SN z 27 listopada 2007 r., IV CSK 239/07, niepublikowany, cyt. za: J. Gudowski, Kodeks postępowania cywilnego. Tekst, orzecznictwo, piśmiennictwo, t. 3, Warszawa 2009, s. 1206/7.

${ }^{16}$ M. Pilich, Klauzula porzqdku publicznego $w$ postępowaniu o uznanie $i$ wykonanie zagranicznego orzeczenia arbitrażowego, „Kwartalnik Prawa Prywatnego” 2003, nr 1, s. 169.

17 Por. szersze rozważania na temat klauzuli porządku publicznego: G. Pagacz, Klauzula porzqdku publicznego $w$ międzynarodowym arbitrażu handlowym, w: Prace laureatów konkursu na najlepsza pracę magisterska dotyczqca problemów sqdownictwa polubownego i mediacji im. prof. dr. hab. Jerzego Jakubowskiego, Warszawa 2012, s. 103-104. Zob. również: M. Kordela, Zasady prawa jako normatywna postać wartości, „Ruch Prawniczy, Ekonomiczny i Socjologiczny” 2006, z. 1, s. 39 i n.; N. Rycko, Stosowanie klauzuli porzqdku publicznego przez polski sqd państwowy w sprawach dotyczqcych arbitrażu, w: Prace laureatów..., s. 204 i n.; Ł. Błaszczak, Wyrok sqdu polubownego $w$ postepowaniu cywilnym, Warszawa 2010, s. 250 i n.

${ }^{18}$ Wyrok SA w Katowicach z 29 grudnia 2006 r., I ACa 1589/2006, Orzecznictwo Sądu Apelacyjnego w Katowicach i Sądów Okręgowych 2007, nr 2, poz. 1, s. 16. 
lubownego byłby więc ewidentnie niezgodny z prawem materialnym, ale jego zaskarżenie do sądu powszechnego okazałoby się nieskuteczne, gdyż w k.p.c. nie ma odpowiedniej podstawy prawnej skargi o uchylenie wyroku sądu polubownego, na którą można by się w tym przypadku powołać. Jednocześnie wspomniany wyrok sądu polubownego zostałby zatwierdzony przez sąd państwowy przez nadanie klauzuli wykonalności, ponieważ nie występuje tu żadna podstawa odmowy stwierdzenia jego wykonalności (por. art. 1214 k.p.c.). Są polubowny bowiem swoim wyrokiem nie naruszyłby w tym przypadku żadnej podstawowej zasady porządku prawnego.

Do podobnych wniosków dojdziemy też w innej przykładowej sytuacji. Oto strony zawarły umowę pożyczki, w której umówiły się także o odsetki jako wynagrodzenie za pożyczoną kwotę. Pożyczkobiorca nie oddał pieniędzy w ogóle, czym zmusił pożyczkodawcę do wystapienia z powództwem o zapłatę. Jeżeli pozew w tej sprawie trafi do sądu państwowego, to wszystko wskazuje na to, że zostanie zasądzona cała należność powoda, a zatem nominalna kwota długu wraz z odsetkami, i tylko tej treści wyrok będzie zgodny z prawem materialnym. Jeżeli natomiast w wyniku kompromisu pozew trafi do sądu arbitrażowego, to jak najbardziej jest do pomyślenia wyrok, w którym zostanie zasądzona jedynie podstawowa kwota długu, ale bez odsetek jako wynagrodzenia dla pożyczkodawcy, albo z odsetkami mniejszymi niż umówione. Sąd polubowny bowiem mógłby żądanie odsetek z tytułu pożyczenia pieniędzy uznać w całości lub części za niesprawiedliwe. Trudno byłoby w tym przypadku dopatrywać się pogwałcenia przez sąd polubowny jakiejś podstawowej zasady porządku prawnego. Mało tego, w odbiorze powszechnym ten wyrok sądu polubownego zostałby uznany za bardziej sprawiedliwy aniżeli wyrok sądu państwowego, gdyż stwierdzono by, że sąd polubowny nie akceptuje roszczeń o charakterze lichwiarskim. Wyrok zatem sądu polubownego byłby częściowo sprzeczny z prawem materialnym, które pozwala - poza przypadkiem wyzysku (art. 388 k.c.) czerpać dochody z pożyczania pieniędzy, ale jednak wyrok ten utrzymałby się w mocy w postępowaniu kontrolnym wszczętym skargą o jego uchylenie.

Powyższe przykłady pokazuja, w jak wielu sprawach cywilnych sady polubowne moga orzekać sprzecznie z prawem materialnym, a pomimo tego ich wyroki staną się skuteczne i wykonalne z powodu braku możliwości ich skutecznego zaskarżenia oraz z powodu braku możliwości odmowy ich uznania lub stwierdzenia ich wykonalności.

Do podobnych wniosków o nieistnieniu związania sądu polubownego prawem materialnym można dojść poprzez analizę postanowień Regulaminu arbitrażowego UNCITRAL ${ }^{19}$. W art. 33 ust. 1 tego regulaminu w brzmieniu obowiąującym do 2010 r. czytaliśmy, że sąd arbitrażowy stosuje prawo wskazane przez strony jako właściwe dla danego sporu. W przypadku braku takiego wskazania przez strony sąd arbitrażowy stosuje prawo określone normami kolizyjnymi przepisów prawa, które uzna za właściwe.

19 Rezolucja nr 31/98 Zgromadzenia Ogólnego ONZ z 15 grudnia 1976 r. - Regulamin arbitrażowy Komisji Organizacji Narodów Zjednoczonych ds. Międzynarodowego Prawa Handlowego (UNCITRAL); tłumaczenie polskie: K. Mąkosa, P. Nowaczyk i A. Kąkolecki, w: „Biuletyn Arbitrażowy" 2007, nr 9, s. 53 i n. 
Z powyższego uregulowania można by wyprowadzić wniosek, że Regulamin UNCITRAL w brzmieniu obowiąujacym w okresie 1976-2010 nakazywał sądom arbitrażowym respektowanie prawa materialnego właściwego dla sprawy.

Związanie prawem materialnym miało jednak wówczas zupełnie inny charakter aniżeli powszechne rozumienie związania sądu przepisami prawa materialnego. Zgodnie z Regulaminem UNCITRAL to strony wskazywały sądowi polubownemu, jakie prawo właściwe ma zastosować. Mogło być to prawo obowiąujące w państwie, w którym miejsce postępowania miał sąd polubowny, ale mogło to być również prawo każdego innego państwa, a także - na co zwracano uwage w doktrynie - także prawo już nieobowiąujące. W rozumieniu zatem Regulaminu UNCITRAL w poprzednim brzmieniu związanie sądu polubownego przepisami prawa materialnego mogło oznaczać związanie arbitrów systemem prawnym obowiązującym na innym kontynencie bądź systemem prawnym obowiązującym sto lat wcześniej. Zwolennicy poglądu o związaniu sądu polubownego prawem materialnym z pewnością nie tego rodzaju związania bronili. W dodatku jeżeli strony nie wskazały prawa właściwego w danej sprawie, arbitrzy sami mieli dokonać wyboru prawa właściwego, ale w oparciu o normy kolizyjne tego prawa, które sami uznali za właściwe. Z cała pewnością zatem poprzednie brzmienie art. 33 ust. 1 Regulaminu UNCITRAL wprowadzało duży zakres dowolności w odniesieniu do stosowania prawa materialnego przez sąd polubowny. Dodajmy jednocześnie, że art. 33 ust. 2 Regulaminu UNCITRAL pozwalał stronom sporu na odrzucenie jakiegokolwiek prawa właściwego i nakazanie arbitrom orzekania na zasadach słuszności (ex aequo et bono).

Komisja ONZ ds. Międzynarodowego Prawa Handlowego uchwaliła nowy tekst Regulaminu arbitrażowego UNCITRAL 29 czerwca 2010 r. Regulamin w nowej wersji wszedł w życie 15 sierpnia 2010 r. ${ }^{20}$ Przedmiot regulacji w dotychczasowym art. 33 Regulaminu przeniesiono do art. 35 nowego Regulaminu i w miejsce dotychczasowego postanowienia, że sąd arbitrażowy stosuje prawa właściwe wskazane przez strony wprowadzono przepis, iż „sąd arbitrażowy stosuje zasady prawa wskazanego przez strony”.

Nowe brzmienie Regulaminu dobitnie wskazuje na to, że ustawodawca międzynarodowy w jeszcze większym niż dotąd stopniu odchodzi od próby wiązania sądów polubownych prawem materialnym na rzecz związania sądów polubownych ogólnymi zasadami prawa (materialnego i procesowego). Obecnie nie ma już zatem wątpliwości, że upadły ostatnie punkty zaczepienia dla obrony poglądu, iż sąd polubowny musi przestrzegać przepisów prawa materialnego.

Stanowisko tej treści dobitnie sformułował w ostatnich latach polski Sąd Najwyższy, stwierdzając, że naruszenie przez sąd arbitrażowy prawa materialnego uzasadnia uchylenie wyroku tego sądu jedynie wtedy, gdy łączy się z pogwałceniem podstawowych zasad porządku prawnego ${ }^{21}$. Rozwijając tę

${ }^{20}$ Szerzej na ten temat: P. Nowaczyk, Nowy Regulamin Arbitrażowy UNCITRAL, „Biuletyn Arbitrażowy" 2010-2011, nr 4, s. 40 i n.

${ }^{21}$ Wyrok SN z 3 września 2009 r., I CSK 53/09, OSNC-ZD 2010, nr A, poz. 25. 
tezę, Sąd Najwyższy wyjaśnił, że wyrok sądu arbitrażowego ulega uchyleniu jedynie wtedy, gdy zdeterminowane jego treścią skutki są nie do pogodzenia z określoną normą zaliczaną do podstawowych zasad porządku publicznego.

Powyższe konkluzje sa jak najbardziej zgodne z idea sądownictwa polubownego, wyrażająca się w swego rodzaju ucieczce od państwowego wymiaru sprawiedliwości w sprawach cywilnych. Strony dokonują zapisu na sąd polubowny właśnie dlatego, że chcą uzyskać wyrok, który zarówno w ich odczuciu, jak i w odbiorze społecznym będzie wyrokiem sprawiedliwym, mądrym i satysfakcjonującym, nawet jeżeli nie będzie zgodny z określonymi przepisami prawa. W wielu przypadkach bowiem strony oczekują rozstrzygnięcia odpowiadającego normom moralnym i poczuciu słuszności, a niekoniecznie zgodnego z przepisami „bezdusznego” prawa. Jeżeli strona nie chce jednak ryzykować, że jej spór z przeciwnikiem zakończyłby się wyrokiem sprzecznym z prawem, to po prostu nie powinna wchodzić na drogę postępowania arbitrażowego, a zatem nie powinna zawierać umowy zapisującej określoną sprawę cywilną sądowi polubownemu. Pomijam tu oczywiście cały problem zdatności arbitrażowej, a zatem wyróżnienia tych spraw cywilnych, w których zapis na sąd polubowny jest niedopuszczalny.

Dodajmy na koniec, że wszelkie rozważania na temat ewentualnego związania sądu arbitrażowego przepisami prawa materialnego stają się bezprzedmiotowe, jeżeli strony zgodnie $\mathrm{z}$ regulaminem UNCITRAL, a także zgodnie z art. $1194 \S 1$ in fine wyraźnie upoważniły sąd polubowny do orzekania nie według prawa właściwego, ale według ogólnych zasad prawa lub zasad słuszności. W takim przypadku zgodnie z wolą stron problem ewentualnego związania sądu arbitrażowego prawem w ogóle nie występuje. Pozostaje natomiast aktualna ogólna ocena wyroku arbitrażowego z punktu widzenia klauzuli porządku publicznego.

dr hab. Krzysztof Knoppek

Profesor Uniwersytetu im. Adama Mickiewicza w Poznaniu

\section{POTENTIAL PROBLEMS ARISING FROM SUBJECTING A COURT OF ARBITRATION TO THE PROVISIONS OF SUBSTANTIVE LAW}

Sum mary

Recently, opinions have been voiced in the doctrine of civil procedure that courts of arbitration should observe all provisions of substantive civil law in the same way as state courts of law. This view is incorrect and cannot be derived from the provisions of Part 5 of the Code of Civil Procedure or the provisions of the UNICITRAL Rules of Arbitration of 2010. Further, the very concept of courts of arbitration is that their decisions will be made taking into account mutual contractual obligations of the parties in dispute, the general legal principles, the principle of fairness and equity, and the established custom. What is more, these courts are not bound to follow any provision of substantive law, and must only respect the fundamental principles of the legal order (the public order clause). Thus, if parties are not happy with such a concept of a court of arbitration the should not subject their civil matters to their jurisdiction. 
Copyright of Journal of Law, Economics and Sociology is the property of Faculty of Law and Administration of Adam Mickiewicz University in Poznan and its content may not be copied or emailed to multiple sites or posted to a listserv without the copyright holder's express written permission. However, users may print, download, or email articles for individual use.

Właścicielem praw autorskich do „Ruchu Prawniczego, Ekonomicznego i Socjologicznego” jest Wydział Prawa i Administracji Uniwersytetu im. Adama Mickiewicza w Poznaniu. Zawartość czasopisma nie może być kopiowana, przesyłana do innych stron internetowych bądź zamieszczana na blogach bez pisemnej zgody wydawcy. Niemniej artykuły można drukować, kopiować lub przesyłać w formie elektronicznej na własny użytek. 